\title{
Kultur und Rasse
}

\author{
Von \\ Franz Boas
}

Mit einer Kurve im Text

Leipzig

Verlag von Veit \& Comp.

1914 
Druck von Metzger \& Wittig in Leipzlg. 